\title{
Distinct patterns of matrix metalloproteinase-2 and -9 expression in normal human cell lines
}

\author{
M.W. ROOMI, J.C. MONTERREY, T. KALINOVSKY, M.RATH and A. NIEDZWIECKI \\ Dr. Rath Research Institute, 1260 Memorex Drive, Santa Clara, CA 95050, USA
}

Received October 13, 2008; Accepted December 23, 2008

DOI: 10.3892/or_00000290

\begin{abstract}
Invasion of surrounding tissues by malignant cells is a complex process mediated by the matrix degrading enzymes. In many solid tumors, the expression of MMPs, especially MMP-2 and MMP-9, is higher in stromal cells than in the tumor cells, suggesting stromal cells as the major source of these enzymes. Cytokines and signal transduction pathways, including those activated by phorbol 12-myristate 13-acetate (PMA), regulate the expression of MMPs. The aim of this study was to examine the pattern of MMP-2 and MMP-9 expression in human normal cells and in PMA-treated cells to determine if specific patterns of expression were associated with tissues of different origin. Epithelial, connective, and muscle tissues were selected since carcinomas, sarcomas, and adenosarcomas are derived from these tissue types, respectively. The cell lines were cultured in their recommended media and supplemented with $10 \%$ FBS and antibiotics in 24-well tissue culture plates. At near confluence, the cells were washed and fresh medium added. A parallel set of cultures was treated with PMA. After $24 \mathrm{~h}$ of incubation, media were collected and analyzed for MMP-2 and MMP-9 by gelatinase zymography. The results indicate that the normal cell expression of MMP-2 and MMP-9 depends on their primary tissue subtype. All cell lines, regardless of tissue origin, expressed MMP-2. PMA induced MMP-9 expression in glandular epithelia, supportive connective tissue, and muscle tissue cell lines. However, cell lines of endothelial origin and proper connective tissue were insensitive to PMA. These results suggest that MMP-2 and MMP-9 are differentially regulated and an understanding of this may open up avenues to use these enzymes as targets for therapy.
\end{abstract}

\section{Introduction}

Tumor invasion of the surrounding tissue and subsequent metastasis is a result of a multi-step process that includes proteolytic disruption of the surrounding extracellular matrix

Correspondence to: Dr Aleksandra Niedzwiecki, Dr. Rath Research Institute, 1260 Memorex Drive, Santa Clara, CA 95050, USA E-mail: author@drrath.com

Key words: MMP-2, MMP-9, stromal cells, phorbol 12-myristate 13-acetate
(ECM), allowing malignant cells to move into and through the ECM and basement membrane (1). Although all five major classes of proteases (serine, aspartic acid, cysteine, threonine, and metalloproteases) are involved in invasion and metastasis, matrix metalloproteinases (MMPs) are particularly implicated in the degradation of various ECM components. Increased secretion of these proteins has been associated with tumor promotion, progression, invasion, angiogenesis, and metastasis $(2,3)$.

MMPs are a growing family of zinc-dependent endopeptidases known for their ability to degrade the ECM. Over twenty different MMPs act on a broad spectrum of substrates, including collagen type I, II, III, IV, and stromyelin. Type IV collagen is a major structural protein for ECM and basement membrane. Type IV collagenases MMP-2 (72-kDa gelatinase A) and MMP-9 (92-kDa gelatinase B) have been the focus of research since MMP-2 and MMP-9 expression is associated with cancer cell invasion and elevated in a variety of malignancies (4-6). A good correlation between elevated MMP-2 and MMP-9 levels and tumor progression and metastasis has been reported in many experimental and clinical studies $(2,3,7-10)$.

Interaction between cancer cells and the surrounding tissue is an important factor in tumor growth and tumor cell invasion of surrounding tissue. In many solid tumors, cells surrounding the tumor undertake the majority of MMP expression rather than the tumor tissue itself (11-13). Stromal tissues communicate with tumor cells and cooperate in tumor progression. Understandably, the type of tissue in which a tumor arises gives it distinguishing characteristics. This is the basis for the current classification of malignant neoplasia. Malignant tumors arising from epithelia constitute $85 \%$ of cancers and are classified as carcinomas, malignant tumors of mesoderm (e.g., bone and muscle) are classified as sarcomas, and malignant tumors of glandular tissue (e.g., breast tissue) are classified as adenocarcinomas. Further investigation into the role of stromal cells in disease progression may prove useful etiologically and for the development of new treatments.

The main objective of this study was to examine the pattern of MMP-2 and MMP-9 expression in normal human cell lines of different primary tissue origin (epithelial, connective tissue, and muscle origin) and to determine the potential up-regulated pattern of MMP-2 and MMP-9 expression, commonly seen in various cancers, through the use of increased protein kinase $\mathrm{C}$ activity via the inducer phorbol 12-myristate 13-acetate (PMA). 


\section{Materials and methods}

Cancer cell lines and reagents. Fifteen human normal cells from three primary tissues (epithelial, connective, and muscle) were investigated (Table I.) Each primary tissue is further divided into subtypes: epithelial tissue into endothelial and glandular; connective tissue into stromal and supportive; and muscle into smooth and skeletal muscle. All cell lines used were purchased from Lonza (Walkersville, MD, USA), along with their recommended media, except for hepatocytes, kidney parenchyma, and gingival cells, which were obtained from ATCC (Manassas, VA, USA) along with their recommended media. Human rheumatoid synovial fibroblasts were isolated from rheumatoid arthritic (RA) membrane via enzymatic dissociation using trypsin-EDTA (Gibco, Grand Island, NY, USA). All other reagents, including fetal bovine serum (FBS), penicillin, streptomycin, PMA, were of high grade and obtained from Sigma (St. Louis, MO).

Cell culture. Cells were grown in their recommended media containing FBS $(10 \%)$, penicillin $(100 \mathrm{U} / \mathrm{ml})$, and streptomycin $(100(\mathrm{~g} / \mathrm{ml})$. Cells were plated in triplicates at a density of $1 \times 10^{5}$ cells $/ \mathrm{ml}$ in 24-well tissue culture plates (Coster, Cambridge, MA) and grown to confluency at $37^{\circ} \mathrm{C}$ and $5 \%$ $\mathrm{CO}_{2}$ in a humidified atmosphere. Serum-supplemented medium was removed and the cell monolayer was washed twice with phosphate-buffered saline (PBS) and once with the recommended serum-free medium. Cells were then cultured in $0.5 \mathrm{ml}$ of serum-free medium in an incubator for $24 \mathrm{~h}$. Parallel sets of cultures were treated with PMA $(100 \mathrm{ng} / \mathrm{ml})$ for induction of MMP-9. The resulting conditioned media were collected separately, pooled, and centrifuged at $4^{\circ} \mathrm{C}$ for $10 \mathrm{~min}$ at $3000 \mathrm{rpm}$ to remove cells and cell debris. The supernatant was collected and used for gelatinase zymography, a highly sensitive assay for gelatinolytic enzymatic activity able to detect both pro and active forms of MMP-2 and -9 .

Gelatinase zymography. Gelatinase zymography was performed in $10 \%$ Novex Pre-cast SDS polyacrylamide gel (Invitrogen Corporation) in the presence of $0.1 \%$ gelatin under non-reducing conditions. Culture media $(20 \mu \mathrm{l})$ were mixed with sample buffer and loaded for SDS-PAGE with Tris-glycine SDS buffer, as suggested by the manufacturer (Novex). Samples were not boiled before electrophoresis. Following electrophoresis the gels were washed twice in $2.5 \%$ Triton X-100 for $30 \mathrm{~min}$ at room temperature to remove SDS. The gels were then incubated at $37^{\circ} \mathrm{C}$ overnight in substrate buffer containing $50 \mathrm{mM}$ Tris- $\mathrm{HCl}$ and $10 \mathrm{mM} \mathrm{CaCl}_{2}$ at $\mathrm{pH} 8.0$ and stained with $0.5 \%$ Coomassie Blue R250 in 50\% methanol and $10 \%$ glacial acetic acid for $30 \mathrm{~min}$ and destained. Upon renaturation of the enzyme, the gelatinases digested the gelatin in the gel, producing clear bands against an intensely stained background. Protein standards were run concurrently and approximate molecular weights were determined by plotting the relative mobilities of known proteins. Gelatinase zymograms were scanned using CanoScan 9950F Canon scanner at $300 \mathrm{dpi}$. The intensity of the bands was evaluated using the pixel-based densitometer program Un-Scan-It, version 5.1, 32-bit, by Silk Scientific Corporation (Orem, UT, USA), at a resolution of 1 Scanner unit (1/100 of an inch for an image that
A

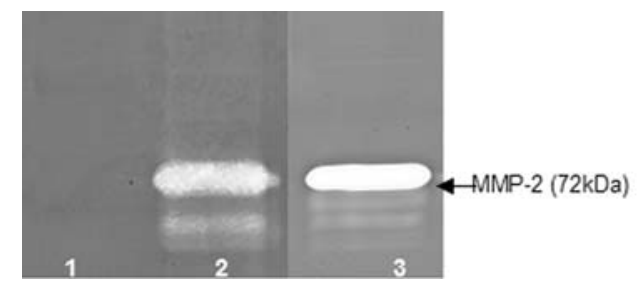

B

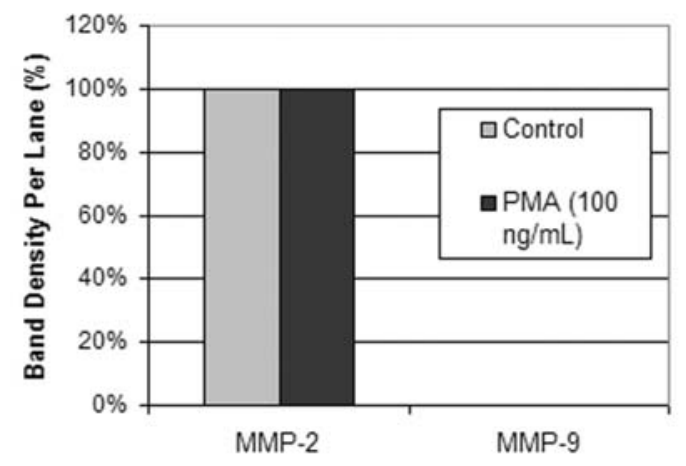

C

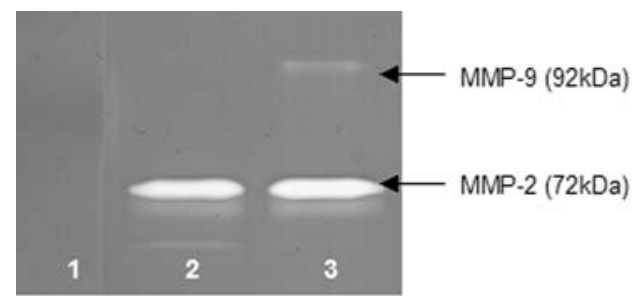

D

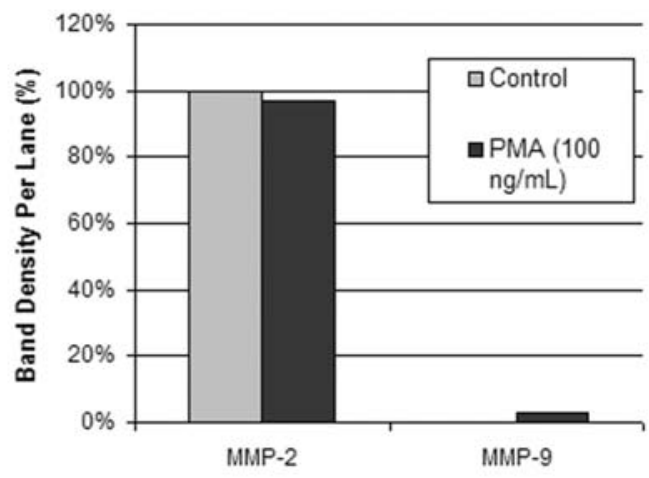

Figure 1. Pattern of MMP-2 and MMP-9 expression in epithelial tissues, without and with PMA. (A) Gelatinase zymogram of human vein endothelial cells (HUVEC), representative of endothelial tissue, expressed only MMP-2, even after PMA treatment. (lanes: 1, markers; 2, control, 3, $100 \mathrm{ng} / \mathrm{ml}$ PMA treatment). (B) Quantitative densitometric analysis of MMP expression of HUVEC gelatinase zymogram. MMP expression is reported as a percentage of the sum of band densities in a given lane. (C) Gelatinase zymogram of human hepatocytes, representative of glandular epithelia, expressed MMP-2 and MMP-9 after PMA treatment. (lanes: 1, markers; 2 , control; 3, $100 \mathrm{ng} / \mathrm{ml}$ PMA treatment). (D) Quantitative densitometric analysis of MMP expression of human hepatocytes gelatinase zymogram. MMP expression is reported as a percentage of the sum of band densities in a given lane.

was scanned at $100 \mathrm{dpi}$ ). The pixel densitometer calculates the optical density of each pixel (values: 0-255) using the darkly stained background of the gel as a pixel value of 0 . A logarithmic optical density scale was used since the optical density of films and gels is logarithmically proportional to the concentration. The pixel densitometer sums the optical density of each pixel to give a band's density. In all graphs, band 
Table I. List of primary cell lines.

\begin{tabular}{|c|c|c|c|c|c|}
\hline \multicolumn{2}{|c|}{ Epithelial tissue } & \multicolumn{2}{|c|}{ Connective tissue } & \multicolumn{2}{|c|}{ Muscle tissue } \\
\hline Endothelium & Glandular & Stromal & Supportive & Smooth & Striated \\
\hline \multirow[t]{5}{*}{$\begin{array}{l}\text { Human vein } \\
\text { endothelium } \\
\text { (HUVEC) }\end{array}$} & $\begin{array}{l}\text { Human } \\
\text { hepatocyte }\end{array}$ & $\begin{array}{l}\text { Normal human } \\
\text { dermal fibroblast } \\
\text { (NHDF) }\end{array}$ & $\begin{array}{l}\text { Normal human } \\
\text { chondrocyte } \\
\text { (NHAC-Kn) }\end{array}$ & $\begin{array}{l}\text { Bronchial } \\
\text { (Br-SMC) }\end{array}$ & $\begin{array}{l}\text { Skeletal } \\
(\text { Sk-SMC) }\end{array}$ \\
\hline & $\begin{array}{l}\text { Kidney } \\
\text { parenchyma }\end{array}$ & $\begin{array}{l}\text { Human gingival } \\
\text { fibroblast (HGF) }\end{array}$ & $\begin{array}{l}\text { Normal human } \\
\text { osteoblast } \\
\text { (NHOst) }\end{array}$ & $\begin{array}{l}\text { Aortic } \\
\text { (Ao-SMC) }\end{array}$ & \\
\hline & $\begin{array}{l}\text { Normal human } \\
\text { epidermal keratinocyte } \\
\text { (NHEK-Ad) }\end{array}$ & $\begin{array}{l}\text { Normal human } \\
\text { lung fibroblast } \\
\text { (NHLF) }\end{array}$ & & $\begin{array}{l}\text { Uterine } \\
\text { (Ut-SMC) }\end{array}$ & \\
\hline & & $\begin{array}{l}\text { Prostate stromal } \\
\text { cells (PrSC) }\end{array}$ & & & \\
\hline & & Synovial fibroblast & & & \\
\hline
\end{tabular}

densities are reported as a percentage of the sum of all pixels in a given lane of a gel. Densitometric results from PMA treated samples were also pooled to test for correlation between MMP-2 and -9 expression.

Statistics. Pearson's correlation coefficient was determined for correlation between MMP-2 and -9 expression using MedCalc software (Markakerke, Belgium).

\section{Results}

MMP-2 and MMP-9 expression in epithelial tissues

Endothelium. Analysis of conditioned media from control and PMA-stimulated human vein endothelial cells (HUVEC) by gelatinase zymography showed a single band at $72 \mathrm{kDa}$, corresponding to MMP-2, and no induction of MMP-9 on PMA treatment (Fig. 1A and B; and Table II).

Glandular epithelia. The glandular epithelial cells analyzed were those of hepatocytes, kidney parenchyma, and keratinocytes. Zymography of conditioned media and quantitative densitometric analyses showed single bands at molecular weight $72 \mathrm{kDa}$, corresponding to MMP-2. On PMA stimulation, these cell lines showed two bands, one band at $72 \mathrm{kDa}$ (MMP-2) and a strong band at molecular weight of $92 \mathrm{kDa}$, corresponding to MMP-9 (Fig. 1 and Table II). A zymograph and densitometric scan for hepatocytes, a typical representative of glandular epithelia, are shown in Fig. 1C and D.

\section{MMP-2 and MMP-9 expression in connective tissues}

Stromal connective tissue. The connective tissues analyzed included NHDF, gingival fibroblasts, lung fibroblasts, synovial fibroblasts, and prostate stromal cells. Expression of MMPs and quantitative densitometric analyses of gelatinase zymograms are provided in Table III. Unstimulated and PMAstimulated conditioned media showed a single band for MMP-2 (72 kDa). A gelatinase zymogram and quantitative
Table II. Pattern of MMP-2 and MMP-9 expression in epithelial cell lines.

\begin{tabular}{|c|c|c|c|c|}
\hline \multicolumn{5}{|c|}{ Endothelia } \\
\hline \multirow[t]{2}{*}{ Cell line } & \multicolumn{2}{|c|}{ Control } & \multicolumn{2}{|c|}{ PMA } \\
\hline & MMP-2 & MMP-9 & MMP-2 & MMP-9 \\
\hline $\begin{array}{l}\text { Human vein } \\
\text { endothelia } \\
\text { (HUVEC) }\end{array}$ & $100 \%$ & $0 \%$ & $100 \%$ & $0 \%$ \\
\hline \multicolumn{5}{|c|}{ Glandular epithelia } \\
\hline \multirow[t]{2}{*}{ Cell line } & \multicolumn{2}{|c|}{ Control } & \multicolumn{2}{|c|}{ PMA } \\
\hline & MMP-2 & MMP-9 & MMP-2 & MMP-9 \\
\hline $\begin{array}{l}\text { Human } \\
\text { hepatocytes }\end{array}$ & $100 \%$ & $0 \%$ & $96 \%$ & $4 \%$ \\
\hline $\begin{array}{l}\text { Kidney } \\
\text { parenchyma }\end{array}$ & $100 \%$ & $0 \%$ & $96 \%$ & $4 \%$ \\
\hline Keratinocytes & $100 \%$ & $0 \%$ & $89 \%$ & $11 \%$ \\
\hline
\end{tabular}

densitometric analysis for NHDF, a representative of this group, are shown in Fig. 2A and B.

Supportive connective tissue. Quantitative densitometric analyses of MMPs for chondrocytes and osteoblasts are shown in Table III. Both supportive connective tissue cell lines exhibited high MMP-2 expression. PMA-treated conditioned media exhibited a band for MMP-2 and a marked increase in MMP-9 expression. A gelatinase zymogram and quantitative densitometric analysis for chondrocytes, a representative of this group, are shown in Fig. 2C and D. 
A

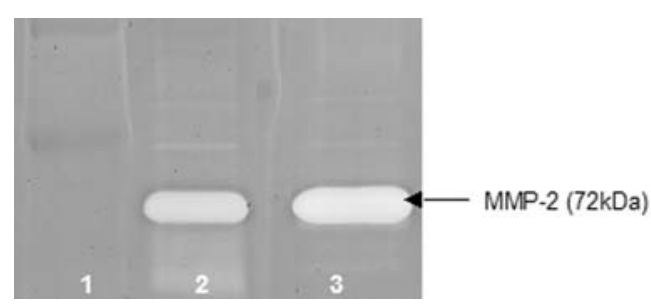

B

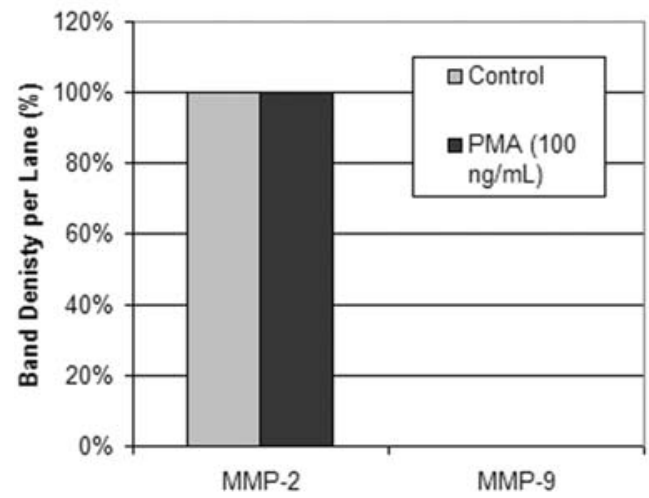

C

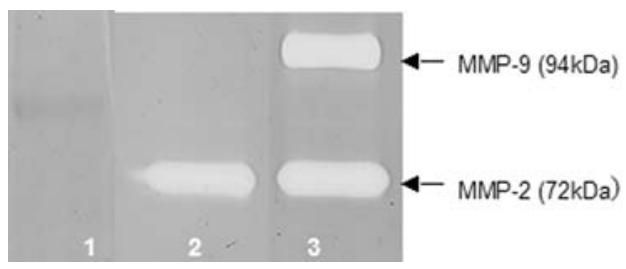

D

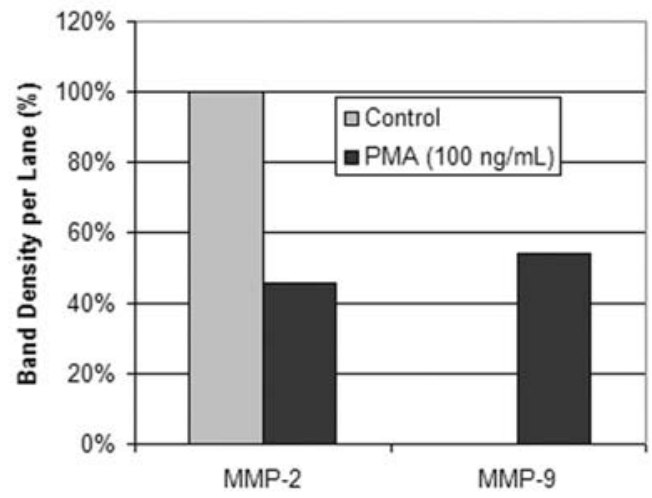

Figure 2. Pattern of MMP-2 and MMP-9 expression in connective tissues, without and with PMA. (A) Gelatinase zymogram of normal human dermal fibroblasts (NHDF), representative of proper connective tissue, expressed only MMP-2, even after PMA treatment. (lanes: 1, markers; 2, control; 3, $100 \mathrm{ng} / \mathrm{ml}$ PMA treatment). (B) Quantitative densitometric analysis of MMP expression of NHDF gelatinase zymogram. MMP expression is reported as a percentage of the sum of band densities in a given lane. (C) Gelatinase zymogram of normal human chondrocytes (NHAC-Kn), representative of supportive connective tissue, expressed MMP-2 and MMP-9 after PMA treatment. (lanes: 1, markers; 2, control; 3, $100 \mathrm{ng} / \mathrm{ml}$ PMA treatment). (D) Quantitative densitometric analysis of MMP expression of NHAC-Kn gelatinase zymogram. MMP expression is reported as a percentage of the sum of band densities in a given lane.

MMP-2 and MMP-9 expression in muscle tissues

Smooth muscle tissue. Three types of human smooth muscle cells were investigated: uterine, bronchial, and aortic. See Table IV for quantitative densitometric analyses of unstimulated and stimulated media. All three smooth muscle cells demonstrated high MMP-2 expression. Bronchial and uterine
A

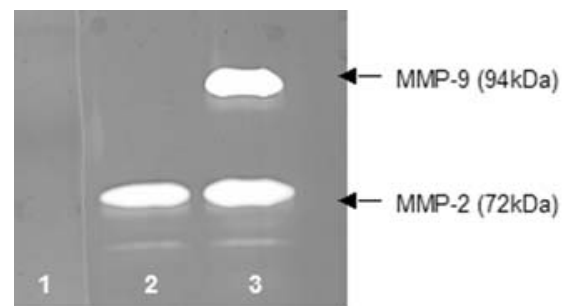

B

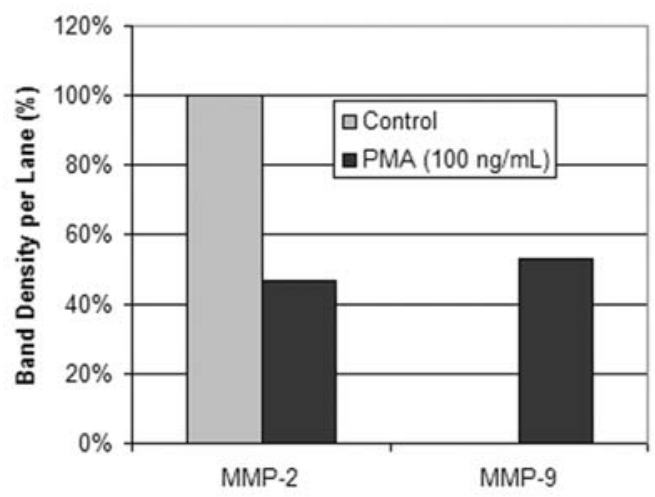

C

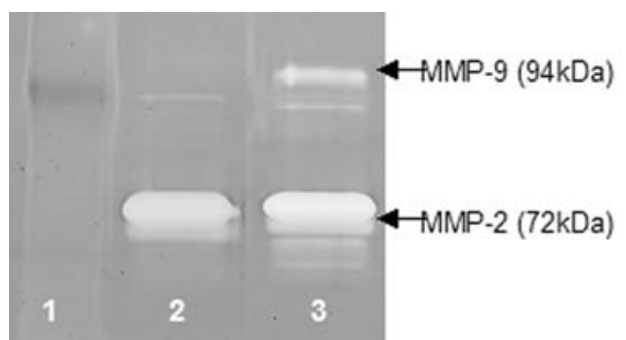

D

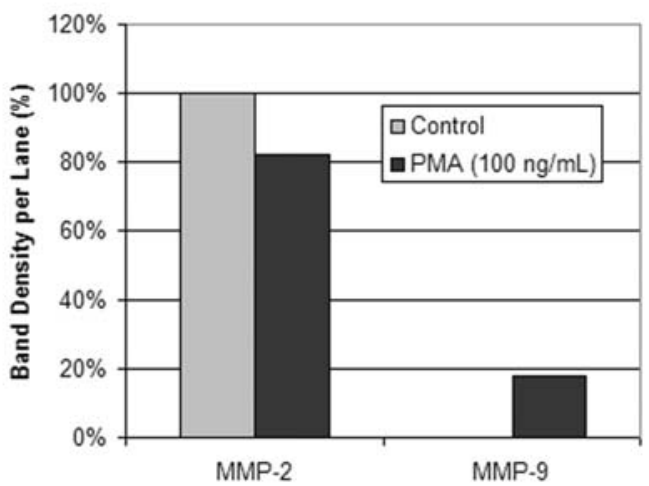

Figure 3. Pattern of MMP-2 and MMP-9 expression in muscle tissues, without and with PMA. (A) Gelatinase zymogram of uterine smooth muscle (Ut-SMC), representative of muscle, expressed MMP-2 and MMP-9 after PMA treatment. (lanes: 1, markers; 2, control; 3, 100 ng/ml PMA treatment). (B) Quantitative densitometric analysis of MMP expression of Ut-SMC gelatinase zymogram. MMP expression is reported as a percentage of the sum of band densities in a given lane. (C) Gelatinase zymogram of skeletal (striated) muscle (Sk-SMC) expressed both MMP-2 and MMP-9 after PMA treatment. (lanes: 1, markers; 2, control; 3, $100 \mathrm{ng} / \mathrm{ml} \mathrm{PMA}$ treatment). (D) Quantitative densitometric analysis of MMP expression of Sk-SMC gelatinase zymogram. MMP expression is reported as a percentage of the sum of band densities in a given lane.

smooth muscle cells exhibited PMA-induced MMP-9 expression. PMA failed to induce MMP-9 expression in aortic smooth muscle cells. This finding is in agreement with previous studies of aortic smooth muscle cell resistance to MMP-9 stimulation by PMA (14). Fig. 3A and B show a 
Table III. Pattern of MMP-2 and MMP-9 expression in connective tissue cell lines.

\begin{tabular}{|c|c|c|c|c|}
\hline \multicolumn{5}{|c|}{ Stromal } \\
\hline \multirow[t]{2}{*}{ Cell line } & \multicolumn{2}{|c|}{ Control } & \multicolumn{2}{|c|}{ PMA } \\
\hline & MMP-2 & MMP-9 & MMP-2 & MMP-9 \\
\hline Dermal fibroblasts & $100 \%$ & $0 \%$ & $100 \%$ & $0 \%$ \\
\hline $\begin{array}{l}\text { Gingival } \\
\text { fibroblasts }\end{array}$ & $100 \%$ & $0 \%$ & $100 \%$ & $0 \%$ \\
\hline Lung fibroblasts & $100 \%$ & $0 \%$ & $100 \%$ & $0 \%$ \\
\hline $\begin{array}{l}\text { Prostate stromal } \\
\text { cells }\end{array}$ & $100 \%$ & $0 \%$ & $100 \%$ & $0 \%$ \\
\hline Synovial fibroblasts & $100 \%$ & $0 \%$ & $100 \%$ & $0 \%$ \\
\hline \multicolumn{5}{|c|}{ Supportive } \\
\hline \multirow[t]{2}{*}{ Cell line } & \multicolumn{2}{|c|}{ Control } & \multicolumn{2}{|c|}{ PMA } \\
\hline & MMP-2 & MMP-9 & MMP-2 & MMP-9 \\
\hline Chondrocytes & $100 \%$ & $0 \%$ & $46 \%$ & $54 \%$ \\
\hline Osteoblasts & $100 \%$ & $0 \%$ & $68 \%$ & $32 \%$ \\
\hline
\end{tabular}

gelatinase zymogram of uterine smooth muscle cells in both induced and uninduced media and a corresponding graph quantitating MMP expression.

Striated muscle cells. Skeletal muscle cells exhibited MMP-2 expression in control media, and both MMP-2 and MMP-9 in PMA treated media, as shown in Fig. 3C and D and Table IV.

Correlation between MMP-9 and MMP-2 expression. Results of a correlation study between MMP-2 and -9 expression yielded a linear negative correlation between MMP-9 expression and MMP-2 expression in the presence of PMA, as shown in Fig. 4 ( $r=-1.000, \mathrm{p}<0.0001)$.

\section{Discussion}

In this study we found MMP-2 to be expressed in all normal human cell lines, whereas MMP-9 was expressed in select cell lines by PMA treatment. The pattern of MMP-2 and MMP-9 expression in the various cell lines segregated according to tissue type. We found that endothelia and stromal connective tissue expressed only MMP-2, but glandular epithelia, supportive connective tissue, and all muscle cells, both smooth and striated, expressed MMP-2 and -9 with PMA treatment. These results contribute to the growing appreciation for stromal cell production of MMPs and their consequent importance in malignant neoplastic processes.

Several studies have localized the major source of in vivo expression of MMP-2 and -9 in the stromal tissue adjacent to tumor cells. The expression of MMPs by cells adjacent to tumor cells implies a close cooperation between tumors and stromal cells. Research on various cancers has localized
Table IV. Pattern of MMP-2 and MMP-9 expression in muscle cell lines.

Smooth

\begin{tabular}{lccccc}
\hline \multirow{2}{*}{ Cell line } & \multicolumn{2}{c}{ Control } & & \multicolumn{2}{c}{ PMA } \\
\cline { 2 - 3 } \cline { 5 - 6 } & MMP-2 & MMP-9 & & MMP-2 & MMP-9 \\
\hline Uterine & $100 \%$ & $0 \%$ & & $47 \%$ & $53 \%$ \\
Bronchial & $100 \%$ & $0 \%$ & & $89 \%$ & $\begin{array}{c}11 \% \\
\text { Aortic }\end{array}$ \\
\cline { 5 - 6 } & $100 \%$ & $0 \%$ & & $100 \%$ & Resistant to \\
& & & & & PMA (0\%) \\
\hline
\end{tabular}

Striated

\begin{tabular}{lccccc}
\hline \multirow{2}{*}{ Cell line } & \multicolumn{2}{c}{ Control } & & \multicolumn{2}{c}{ PMA } \\
\cline { 2 - 3 } \cline { 5 - 6 } & MMP-2 & MMP-9 & & MMP-2 & MMP-9 \\
\hline Skeletal & $100 \%$ & $0 \%$ & & $82 \%$ & $18 \%$ \\
\hline
\end{tabular}

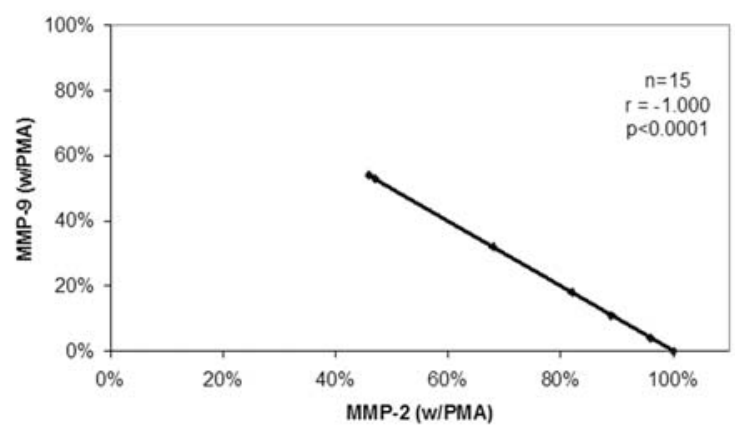

Figure 4. Correlation of MMP-2 and MMP-9 levels. A linear negative correlation between MMP-9 and MMP-2 expression in the presence of PMA was obtained with correlation coefficient $\mathrm{r}=-1.000, \mathrm{p}<0.0001$ ), $\mathrm{n}=15$.

gelatinases by in situ hybridization both in cancer cells themselves and in mesenchymal cells adjacent to the invading tumor front $(12-13,15)$. A glycoprotein at the surface of cancer cells termed extracellular matrix metalloproteinase inducer (EMMPRIN) was found to stimulate these peritumor fibroblasts (11). Thus, EMMPRIN plays a role in invasion and metastasis of cancer cells by stimulating nearby fibroblasts to secrete increased amounts of interstitial collagenase, stromelysin-1, and gelatinase A (16).

For example, early invasion of malignant melanoma was found to be associated with de novo expression of gelatinase B and EMMPRIN by neoplastic melanocytes (17). By in situ hybridization of breast cancer tissue, stromelyn-3 mRNA was detected exclusively in stromal cells not cancer cells (18). Colon adenocarcinoma u-PA immunoreactivity and mRNA were found in fibroblast-like cells in the tumor stroma and not in the cancer cells (13).

As a member of the immunoglobulin superfamily, EMMPRIN is involved in intercellular recognition $(19,20)$, but unfortunately, the mechanism by which it regulates MMP expression is poorly understood. Nonetheless, acknowledging 
the cross-talk between cells surrounding tumors and tumor cells is important as it suggests stromal cells need not become cancerous to be malignant. Extensive cross-talk between tumor cells and their surrounding tissue induces stromal cells to become altered cells. Indeed, Liotta and Kohn (21) found that cells surrounding tumors often supported, if not promoted, tumor growth. Cross-talk between malignant and stromal cells may induce normal cells to become altered, which can affect the tumor-stromal system as a whole. In vitro co-culture experiments of normal fibroblasts with tumor cell lines such as prostate, breast, colon, lung, and melanoma, have demonstrated high expressions of MMP-2 and MMP-9 otherwise not seen; neither fibroblasts nor these cancer cell lines express MMP-2 and -9 at substantial levels when monocultured (22-24). These results suggest that co-culturing cancer cells with normal fibroblasts triggers alteration of the fibroblasts to support further cancer cell growth by secretion of MMPs, leading to ECM degradation, attachment to ECM components, and cellular motility. The complexity of tumor-stromal interactions has even prompted some to refer to it as a 'new organ' (25).

Since MMPs play an integral role in nearly every neoplastic process, one would expect similar patterns of up-regulated MMP expression in cell lines of related tissues. All normal human cell lines investigated expressed MMP-2 but varied in responsiveness to PMA-induction of MMP-9 expression. MMP patterns of expression were associated with primary tissue subtypes. Thus, within the epithelial tissue group, endothelial tissue cells expressed only MMP-2, even after treatment with PMA, but glandular tissue expressed both MMP-2 and -9 after PMA treatment. In connective tissue, stromal connective tissue expressed only MMP-2, even after PMA treatment, whereas supportive connective tissue expressed both MMP-2 and -9 after PMA induction. In both smooth and striated muscle tissue, all cell lines expressed MMP-2, and both MMP-2 and -9 when treated with PMA. Since stromal cells appear to be the primary source of upregulated MMP expression, further studies in stromal-tumor cell interactions is indicated.

\section{Acknowledgements}

We would like to thank Dr D.S.R. Sarma for his valuable suggestions. The research study was funded by Dr Rath Health Foundation (Plantation, FL, USA), a non-profit organization.

\section{References}

1. Fidler IJ: Molecular biology of cancer: Invasion and metastasis. In: Cancer: Principles and Practice of Oncology. De Vita VT, Hellman S and Rosenberg SA (eds). 5th edition, LippincottRaven, Philadelphia, PA, pp135-152, 1997.

2. Liotta LA, Tryggvason K, Garbisa A, Hart I, Foltz CM and Shafie S: Metastatic potential correlates with enzymatic degradation of basement membrane collagen. Nature 284: 67-68, 1980 .

3. Stetler-Stevenson WG: The role of matrix metalloproteinases in tumor invasion, metastasis and angiogenesis. Surg Oncol Clin N Am 10: 383-392, 2001.

4. Bernhard EJ, Muschel RJ and Hughes EN: Mr 92,000 gelatinase release correlates with the metastatic phenotype in transformed rat embryo cells. Cancer Res 50: 3872-3877, 1990.

5. Sato H, Kida Y, Mai M, Endo Y, Sasaki T, Tanaka J and Seiki H: Expression of genes encoding type IV collagen-degrading metalloproteinases and tissue inhibitors of metalloproteinases in various human tumor cells. Oncogene 7: 77-83, 1992.
6. Stetler-Stevenson WG: Type IV collagenases in tumor invasion and metastasis. Cancer Metastasis Rev 9: 289-303, 1990.

7. Cottam DW, Rennie IG, Woods K, Parsons MA, Bunning RA and Rees RC: Gelatinolytic metalloproteinase secretion patterns in ocular melanoma. Invest Ophthalmol Vis Sci 32: 1923-1927, 1992.

8. Fishman DA, Bafetti L, Banionis S, Kearns AS, Chilukuri K and Stack MS: Production of extracellular matrix degrading proteinases by primary cultures of human epithelial ovarian carcinoma cells. Cancer 80: 1457-1463, 1997.

9. Garzetti G, Ciavattini A, Lucarini G, Goteri G, de Nicolis M, Garbisa S, Masiero L, Romanini C and Graziella B: Tissue and serum metalloproteinase (MMP-2) expression in advanced ovarian serous cytstadenocarcinomas: clinical and prognostic implications. Anticancer Res 15: 2799-2804, 1995.

10. Gohji K, Fujomoto N, Hara I, Fujii A, Gotoh A, Okada H, Arakawa S, Kitazawa S, Miyake H, Kamidono S and Nakijima M: Serum matrix metalloproteinase-2 and its density in men with prostate cancer as a new predictor of disease extension. Int $\mathrm{J}$ Cancer 79: 96-101, 1998.

11. Biswas C, Zhang Y, De Castro R, Guo H, Nakamura T, Ktaoka H and Nabeshima K: The human tumor cell-derived collagenase stimulatory factor (renamed EMMPRIN) is a member of the immunoglobulin superfamily. Cancer Res 55: 434-439, 1995.

12. Pyke C, Ralfkiaer E, Huhtala P, Hurskainen T, Dano K and Tryggvason K: Localization of messenger RNA for Mr 72,000 and 92,000 type IV collagenases in human skin cancers by in situ hybridization. Cancer Res 52: 1336-1341, 1992.

13. Pyke C, Kristensen P, Ralfkiaer E, Gröndahl-Hansen J, Eriksen J Blasi F and Dano K: Urokinase-type plasminogen activator is expressed in stromal cells and its receptor in cancer cells at invasive foci in human colon adenocarcinomas. Am J Pathol 138: 1059-1067, 1991 .

14. Yang JH, Sakamoto H, Xu EC and Lee RT: Biomechanical regulation of human monocyte/macrophage molecular function. Am J Pathol 156: 1797-1804, 2000.

15. Di Nezza LA, Misajon A, Zhang J, Jobling T, Quinn MA, Ostör AG, Nie G, Lopata A and Salamonsen LA: Presence of active gelatinases in endometrial carcinoma and correlation of matrix metalloproteinase expression with increasing tumor grade and invasion. Cancer 94: 1466-1475, 2002.

16. Kataoka H, DeCastro R, Zucker S and Biswas C: Tumor cellderived collagenase-stimulating factor increases expression of interstitial collagenase, stromelysin and 72-kDa gelatinase. Cancer Res 53: 3154-3158, 1993.

17. Van den Oord JJ, Paemon L, Opdenakker C and De Wolf-Peters C: Expression of gelatinase $\mathrm{B}$ and the extracellular matrix metalloproteinase inducer EMMPRIN in benign and malignant pigment cell lesions of the skin. Am J Pathol 151: 665-670, 1997.

18. Basset P, Bellocq JP, Wolf C, Stoll I, Hutin P, Limacher JM, Podhajcer OL, Chenard MP, Rio MC and Chambon P: A novel metalloproteinase gene specifically expressed in stromal cells of breast carcinomas. Nature 348: 699-704, 1990.

19. Miyauchi T, Masuzawa Y and Muramatsu T: The basigin group of the immunoglobulin superfamily: complete conservation of a segment in and around transmembrane domains of human and mouse basigin and chicken HT7 antigen. J Biochem 110: 770-774, 1991.

20. Kanekura T, Miyauchi T, Tashiro M and Muramtsu T: Basigin, a new member of the immunoglobulin superfamily: genes in differenct mammalian species, glycosylation changes in the molecule from adult organs and possible vaiation in the $\mathrm{N}$ terminal sequencs. Cell Struct Funct 16: 23-30, 1991.

21. Liotta LA and Kohn EC: The microenvironment of the tumorhost interface. Nature 411: 375-379, 2001.

22. Maneva-Radicheva L, Ebert U, Dimoudis N and Altankov G: Fibroblast remodeling of adsorbed collagen type IV is altered in contact with cancer cells. Histol Histopathol 23: 833-842, 2008.

23. Ko K, Yazumi S, Yoshikawa K, Konda Y, Nakajima M, Chiba T and Takahashi R: Activation of fibroblast-derived matrix metalloproteinase- 2 by colon cancer cells in no-contact cocultures. Int J Cancer 87: 165-171, 2000.

24. Sato T, Sakai T, Noguchi Y, Takta M, Hirakawa S and Ito A: Tumor-stromal cell contact promotes invasion of human uterine cervical carcinoma cells by augmenting the expression and activation of stromal matrix metalloproteinases. Gynecol Oncol 92: 47-56, 2004.

25. Bisell MJ and Radisky D: Putting tumors in context. Nature Rev Cancer 1: 46-54, 2001. 